\title{
Gonorrhoea in women and exposure to risk
}

\author{
J. YARNELL AND R. SAMWAYS \\ St. Thomas' Hospital, London
}

\section{Summary}

Data are presented on the characteristics of women with newly diagnosed gonorrhoea who attended Lydia Clinic, St. Thomas' Hospital, during a 6month period. Although gonorrhoea in women is largely asymptomatic, there was strong circumstantial evidence to suggest that some women had attended because they had been exposed to risk. The proportion of women thus motivated was largest among those women who had attended a clinic for sexually transmitted diseases before-in which up to 40 per cent. of women had apparently attended entirely of their own accord.

Women born in the West Indies differed from their counterparts born in the United Kingdom in three respects: they were younger, recorded fewer contacts, and referred themselves less frequently to the clinic for a first visit.

Implications for health education and for future research are discussed.

\section{Introduction}

The largely asymptomatic nature of gonorrhoea in women is a major consideration in the planning of any programme for the control of the disease. Contact tracing results in the treatment of many asymptomatic women with the disease, but the majority of available evidence suggests that many others are not traced. In Belfast, for example, Pemberton, McCann, Mahony, MacKenzie, Dougan, and Hay (1972) found strong indirect evidence for the existence of a pool of infected women-the casual primary contacts of male clinic attenders-who did not themselves attend the clinic.

Health education is also used in programmes for the control of gonorrhoea: posters and leaflets from the Scottish Health Education Unit emphasize the need for attendance for a check-up at a clinic for sexually transmitted disease (STD) should a casual sexual encounter have occurred; and a circular for social workers and probation officers from the

Received for publication November 11, 1975

Address for reprints: Dr J. Yarnell, D.P.H., MRC Epidemiology

Research Unit (South Wales), 4 Richmond Rd., Cardiff, CF2 3AS
Department of Health and Social Security (1973) urges that young women in certain 'at risk' groups be encouraged to attend such clinics for examination and tests after any casual sexual encounters.

Since 1971 a programme of public health education on STD has been conducted in the London boroughs of Lambeth and Wandsworth. In the present study data routinely collected by the Health Workers in Contact Tracing at Lydia Clinic, St. Thomas' Hospital-the clinic serving the boroughs-have been used to explore the factors associated with the attendance of women with gonorrhoea at the clinic. In particular, in view of the health education activity in the boroughs, evidence was sought to determine the proportion of women who attended the clinic of their own accord following exposure to risk.

\section{Method}

During the period October 1, 1973, to March 31, 1974, 408 new cases of gonorrhoea were diagnosed in women attending Lydia Clinic; 381 were referred to the health workers in contact tracing and are the subjects of the present study. Patient data, from records which had been specially designed for contact tracing, were transferred to punched cards and analysed by the Medical Research Division of the Health Education Council.

\section{Results}

Characteristics of women with gonorrhoea who were not referred to the health workers in contact tracing, did not differ significantly from those of women included in the study.

Table I shows the principal characteristics of the study population.

\section{History of previous attendance}

In Table I (item 6) three categories of patients are defined; those who had no history of previous attendance at Lydia Clinic or of STD (first attenders); those who had attended Lydia Clinic on one or more occasions before the study period (previous attenders); and those who had a history of STD but had not attended Lydia Clinic before. The three groups were found to differ significantly from each 
TABLE I Characteristics of new cases a gonorrhoea in women attending Lydia Clinic during study period

\begin{tabular}{|c|c|c|}
\hline Characteristics & No. & Per cent. \\
\hline $\begin{array}{l}\text { 1. Age values (yrs) } \\
\text { Mean } 23 ; \text { median } 21 ; \text { modal } 19 \\
\text { Percentage under } 17 \text { years of age }=7 \text { (27 } \\
\text { women) }\end{array}$ & & \\
\hline \multirow[t]{2}{*}{$\begin{array}{l}\text { 2. Diagnosis } \\
\text { Gonorrhoea only } \\
\text { Gonorrhoea plus candidiasis or trichomoniasis }\end{array}$} & $\begin{array}{l}266 \\
115\end{array}$ & $\begin{array}{r}70 \\
30\end{array}$ \\
\hline & 381 & 100 \\
\hline \multirow[t]{2}{*}{$\begin{array}{l}\text { 3. Marital status } \\
\text { Single } \\
\text { Married } \\
\text { Divorced } \\
\text { Separated }\end{array}$} & $\begin{array}{r}278 \\
65 \\
9 \\
29\end{array}$ & $\begin{array}{r}73 \\
17 \\
2 \\
8\end{array}$ \\
\hline & 381 & 100 \\
\hline \multirow[t]{2}{*}{$\begin{array}{l}\text { 4. Place of birth } \\
\text { United Kingdom } \\
\text { West Indies } \\
\text { Born elsewhere }\end{array}$} & $\begin{array}{r}227 \\
122 \\
32\end{array}$ & $\begin{array}{r}60 \\
32 \\
8\end{array}$ \\
\hline & 381 & 100 \\
\hline \multirow[t]{2}{*}{$\begin{array}{l}\text { 5. Mode of referral } \\
\text { Own accord } \\
\text { Contact slip } \\
\text { Sent by a sexual contact } \\
\text { General practitioner } \\
\text { Health worker in contact tracing } \\
\text { Other }^{\mathrm{c}}\end{array}$} & $\begin{array}{r}77 \\
100 \\
114 \\
29 \\
16 \\
45\end{array}$ & $\begin{array}{r}20 \\
26 \\
30 \\
8 \\
4 \\
4 \\
12\end{array}$ \\
\hline & $\overline{381}$ & 100 \\
\hline \multirow[t]{2}{*}{$\begin{array}{l}\text { 6. History of previous attendance } \\
\text { None } \\
\text { Previous attendance at Lydia } \\
\text { Previous STD but not attended Lydia before }\end{array}$} & $\begin{array}{r}232 \\
121 \\
28\end{array}$ & $\begin{array}{r}61 \\
32 \\
7\end{array}$ \\
\hline & 381 & 100 \\
\hline \multirow[t]{2}{*}{$\begin{array}{l}\text { 7. Number of contacts per case recorded by } \\
\text { interviewer } \\
\text { One only } \\
\text { Two or more }\end{array}$} & $\begin{array}{l}260 \\
120\end{array}$ & $\begin{array}{l}68 \\
32\end{array}$ \\
\hline & $\overline{380^{e}}$ & 100 \\
\hline
\end{tabular}

Tables show the distribution of new cases of gonorrhoea: during the study period eleven patients each contributed two new cases of gonorrhoea

bNumber of patients referred by direct health worker action. The majority of female cases referred by contact slips or by a sexual contact were seen as a consequence of the contact interviews. Clearly the proportion of male patients sufficiently motivated to locate and refer their contacts is largely dependent upon the success of each patient/health worker interview

Includes multiple modes of referral

dPrevious attendance at Lydia does not necessarily denote the presence of previous STD.

eOne patient who denied any sexual contact has been excluded from this total.

other in three respects: marital status; place of birth; and the mode of referral to the clinic. Tables IIA and $B$ show these results.

\section{Mode of referral to the clinic}

The characteristics of women who had attended the clinic of their own accord were particularly examined.
TABLE IIA Percentage distribution of cases by marital status, place of birth, number of contacts, and history of previous attendance

\begin{tabular}{|c|c|c|c|}
\hline $\begin{array}{l}\text { Previous } \\
\text { attendance }\end{array}$ & $\begin{array}{l}\text { None } \\
\text { ( } 232 \text { cases) }\end{array}$ & $\begin{array}{l}\text { At } L y \text { dia } \\
\text { (121 cases })\end{array}$ & $\begin{array}{l}\text { Previous } S T D \\
\text { but not attended } \\
\text { Lydia before } \\
(28 \text { cases })\end{array}$ \\
\hline \multirow[t]{2}{*}{$\begin{array}{l}\text { Marital status } \\
\text { Single } \\
\text { Married } \\
\text { Divorced } \\
\text { Separated }\end{array}$} & $\begin{array}{r}75 \\
17 \\
3 \\
5\end{array}$ & $\begin{array}{r}74 \\
17 \\
2 \\
7\end{array}$ & $\begin{array}{r}50 \\
18 \\
4 \\
28\end{array}$ \\
\hline & 100 & 100 & 100 \\
\hline \multirow[t]{2}{*}{$\begin{array}{l}\text { Place of birth } \\
\text { West Indies } \\
\text { United Kingdom } \\
\text { Elsewhere }\end{array}$} & $\begin{array}{l}28 \\
62 \\
10\end{array}$ & $\begin{array}{r}44 \\
51 \\
5\end{array}$ & $\begin{array}{l}14 \\
75 \\
11\end{array}$ \\
\hline & 100 & 100 & 100 \\
\hline \multirow[t]{2}{*}{$\begin{array}{l}\text { Number of contacts } \\
\text { One } \\
\text { Two or more }\end{array}$} & $\begin{array}{l}67 \\
33\end{array}$ & $\begin{array}{l}76 \\
24\end{array}$ & $\begin{array}{l}50 \\
50\end{array}$ \\
\hline & 100 & 100 & 100 \\
\hline
\end{tabular}

a $\chi^{2}{ }_{1}$ test (Separated cases against all other categories combined: previous STD against none) $=16.11 ; P<0.001$

b $\chi^{2}{ }_{1}$ test (West Indies cases against other categories combined: previous attendance against none) $=8.21 ; \mathrm{P}<0.005$.

TABLE IIB Percentage distribution of cases by mode of referral and history of previous attendance

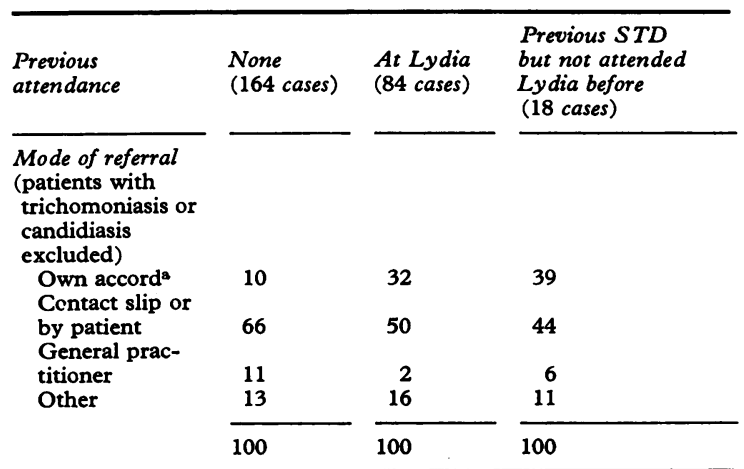

a $\chi^{2} 8$ test (Own accord against all other categories combined: none against previous attendance against previous STD) $=21 \cdot 84$; $P<0.001$

It was assumed that such women must have attended either because they had significant symptoms, or because they were aware that they might have a sexually transmitted disease. In the absence of direct referral from a sexual contact, a certain proportion of women who had no significant symptoms must have attended because they knew that they had been exposed to the risk of infection.

In a study of attendance motivation in Belfast, Mahony (1972) reported that only two women (from 130) with gonorrhoea alone had attended because of symptoms compared with 20 per cent. of 71 
women with trichomoniasis in addition to gonorrhoea. In the present study, therefore, patients with gonorrhoea alone and patients with trichomoniasis or candidiasis in addition to gonorrhoea, have been considered separately.

A further assumption has been made in the present study: that women who had named two or more contacts were more aware that they had been exposed to the risk of infection than women who had named only one contact.

Table III shows the influence of these factors on attendance.

\section{Place of birth}

The women's places of birth were used to detine three ethnic categories (Table I, item 4). Women born in the West Indies were consistently younger than women in either of the other ethnic categories. Thus the median age of West Indian women was one year less than that for the other categories in both first and previous attenders.

Table IV confirms this finding in patients of 16 years of age or less.

West Indian-born women tended to record fewer contacts than did women born in the United Kingdom. This tendency, shown in Table V, was apparent in both first and previous attenders; it is consistent with the view that women born in the West Indies were more likely to be the secondary contacts of male clinic attenders than were women born in the United Kingdom.

Of the patients who had attended Lydia Clinic of their own accord and for the first occasion, fourteen were born in the United Kingdom and only one in the West Indies. This difference was statistically significant. Thus West Indian-born women tended to refer themselves less frequently to the clinic for the first occasion than did women born in the

TABLE III Percentage of self-referred cases by number of recorded contacts and history of previous attendance

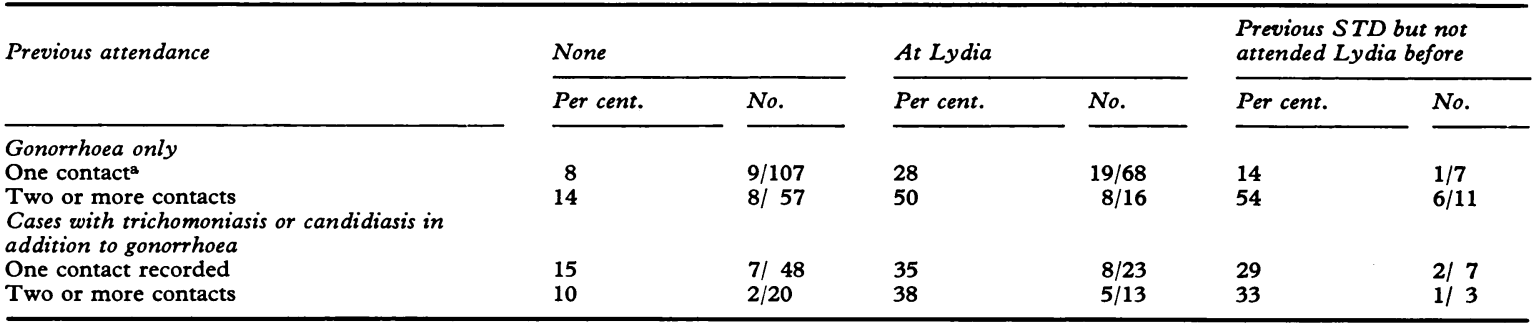

${ }^{a} \chi^{2}{ }_{1}$ test (All attendance categories combined : self-referred against not self-referred ; one contact against two or more contacts) $=3.89$; $\mathbf{P}<0.050$

TABLE IV Percentage of cases in girls aged 16 years or less by place of birth and history of previous attendance

\begin{tabular}{|c|c|c|c|c|c|}
\hline Place of birth & & \multicolumn{2}{|c|}{ United Kingdom } & \multicolumn{2}{|c|}{ West Indies } \\
\hline Previous attendance & $\begin{array}{l}\text { None }^{\mathrm{a}} \\
\text { At Lydia } \\
\text { Previous STD but not attended Lydia before }\end{array}$ & $\begin{array}{l}6 \\
6 \\
5\end{array}$ & $\begin{array}{l}9 / 142 \\
4 / 62 \\
1 / 21\end{array}$ & $\begin{array}{r}17 \\
4 \\
0\end{array}$ & $\begin{array}{r}11 / 65 \\
2 / 53 \\
0 / 4\end{array}$ \\
\hline
\end{tabular}

${ }^{\mathrm{a}} \chi^{2}{ }_{1}$ test (Under 16 yrs against all other ages: West Indies against United Kingdom) $=5 \cdot 75 ; P<0 \cdot 025$

$\mathrm{TABLE} \mathrm{V} \quad$ Percentage of cases in women naming two or more contacts by history of previous attendance and place of birth

\begin{tabular}{|c|c|c|c|c|c|c|c|}
\hline Place of birth & & \multicolumn{2}{|c|}{ United Kingdom } & \multicolumn{2}{|c|}{ West Indies } & \multicolumn{2}{|l|}{ Elsewhere } \\
\hline $\begin{array}{l}\text { Previous } \\
\text { attendance }\end{array}$ & $\begin{array}{l}\text { None }^{\mathrm{a}} \\
\text { Previous attendance }^{\mathrm{b}} \text { at Lydia } \\
\text { Previous STD } \mathrm{D}^{\mathrm{c}} \text { but not attended } \\
\text { Lydia before }\end{array}$ & $\begin{array}{l}38 \\
33 \\
57\end{array}$ & $\begin{array}{l}54 / 144 \\
20 / 61 \\
12 / 21\end{array}$ & $\begin{array}{r}20 \\
15 \\
0\end{array}$ & $\begin{array}{r}13 / 65 \\
8 / 53 \\
0 / 4\end{array}$ & $\begin{array}{l}43 \\
17 \\
67\end{array}$ & $\begin{array}{r}10 / 23 \\
1 / 6 \\
2 / 3\end{array}$ \\
\hline
\end{tabular}

a $\chi^{2}{ }_{1}$ test (Two or more contacts against once contact; United Kingdom against West Indies) $=5.52 ; P<0.025$

b $\chi^{2} 1$ test (Two or more contacts against one contact: United Kingdom against West Indies) $=3 \cdot 88 ; P<0 \cdot 050$

c Fisher's exact test ( $T$ wo or more contacts against one contact; United Kingdom against West Indies: one df); $P=0.057$ 
United Kingdom. This tendency was not apparent in previous attenders.

\section{Discussion}

Of all female clinic attenders with newly diagnosed gonorrhoea, 39 per cent. had attended a clinic for STD on one or more previous occasions before the study period (Table I). Thus, about two-fifths of all women who attended the clinic for the first time with gonorrhoea could be expected to return at a later date with a further infection. If the study clinic is representative of other clinics, these results suggest that the clinic for STD should be regarded as an important focal point for health education and preventive advice. Burton (1969) has discussed the roles of the genito-urinary physician and the health worker in contact tracing and stressed their importance in health education; Alkhateeb, Lukeroth, and Riggs (1975), who compared three educational techniques used in a clinic, found the interview technique to be the most effective.

Women who had previously attended the clinic were more likely to have attended of their own accord than women who attended with a first infection (Table IIB). This finding is consistent with the view that previous attenders were more aware that they might have a sexually transmitted disease than were first attenders.

Similarly, the results in Table III are consistent with the view that women who had named two or more contacts were more aware of the possibility of infection than women who had named only one contact. However, only 14 per cent. of first attenders who had named two or more contacts had attended of their own accord. Thus, only a small proportion of women who were probably aware that they had been exposed to risk had attended of their own accord, although public health education had been conducted in the boroughs. Because of the nature of the study design it was not possible fully to evaluate the public health education in the present study; study designs for full evaluation of health education programmes have been described elsewhere (WHO, 1969).

The patterns of attendance of West Indian-born women differed significantly from those of the other ethnic categories (Tables IV and V). In Jamaica, George (1974) found a modal age for first sexual intercourse of 13 to 15 years in a sample of 178 women who had attended an antenatal clinic. Schofield (1973) has described the pattern of sexual behaviour in English teenage girls and young women.

Cultural factors which influence the development of sexual behaviour warrant further research; other authors have stressed the need for social and behavioural research (Willcox, 1973).

Three main conclusions can be drawn from the study: that the clinic for STD appears to be an appropriate setting for health education and preventive advice; that health education, whether conducted in the clinic or in the community, should be fully evaluated by appropriate techniques; and that further research should be conducted into the cultural factors which influence the development of sexual behaviour.

The authors thank Dr. John Dale and Dr. C. S. Nicol for their help in the preparation of this paper and all others who have given advice.

\section{References}

AlkHATEEB, W., LUKeroth, C. J., and Riggs, M. (1975) Publ. Hlth Rep. (Wash.), 90, 159

BURTON, J. (1969) Hlth Educ. F., 28, 81

Department of Health and Social Security (1973) Memorandum No. Dd 233428: 11/73. HMSO, London

GrORGE, W. F. (1974) Brit. F. vener. Dis., 50, 222

MAHONY, J. D. H. (1972) Ibid., 48, 71

Pemberton, J., McCann, J. S., Mahony, J. D. H., MacKenzIE, G., Dougan, H., and Hay, I. (1972) Ibid., 48, 391

SCHOFIELD, M. (1973) 'The Sexual Behaviour of Young Adults'. Allen Lane, London

Willcox, R. R. (1973) Brit. f. clin. Pract., 27, 247

WORLD Health Organization (1969) 'Research in Health Education', Tech. Rep. Ser. No. 432. W.H.O., Geneva 